\title{
The influence of environmental temperatures on farrowing rates and litter sizes in South African pig breeding units
}

\begin{abstract}
Authors:
Leana Janse van Rensburg ${ }^{1}$

Brian T. Spencer ${ }^{2}$

Affiliations:

${ }^{1}$ Department of Agriculture, Forestry and Fisheries, South Africa

${ }^{2}$ Department of Production Animal Studies, University of Pretoria, South Africa
\end{abstract}

Correspondence to: Leana Janse van Rensburg

Email:

leanajvr@daff.gov.za

Postal address:

Private Bag X138, Pretoria

0001, South Africa

Dates:

Received: 23 June 2014

Accepted: 21 Aug. 2014

Published: 20 Nov. 2014

How to cite this article: Janse van Rensburg, L. \& Spencer, B.T., 2014, 'The influence of environmental temperatures on farrowing rates and litter sizes in South African pig breeding units', Onderstepoort Journal of Veterinary Research 81(1), Art. \#824, 7 pages. http:// dx.doi.org/10.4102/ojvr. v81i1.824

Copyright:

(C) 2014. The Authors.

Licensee: AOSIS

OpenJournals. This work

is licensed under the

Creative Commons

Attribution License.

Read online

Scan this QR code with your smart phone or mobile device to read online.
The reproductive performance of pigs is one of the main determinants of the profit farmers make from pig production. This study was undertaken to describe whether periods of high environmental temperature have an effect on the farrowing rate, litter sizes and number of stillbirths in commercial breeding units in South Africa. Data were collected weekly from four commercial breeding units with good records from December 2010 to August 2012. These data included the number of sows mated, number of sows farrowed and number of piglets born alive, as well as the number of stillbirths. Note was also taken of whether environmental temperature control mechanisms were employed. Temperature data from weather stations within $100 \mathrm{~km}$ of the breeding units were obtained from the South African Weather Service. In all breeding units a decrease in farrowing rate following mating during severe average temperatures $\left(>30^{\circ} \mathrm{C}\right)$ when compared to the farrowing rate following mating during mild average temperatures $\left(<22^{\circ} \mathrm{C}\right)$ was observed. When mating occurred at higher temperatures, the resultant litter size was marginally decreased in the breeding units that did not employ environmental temperature control, but was unaffected in the breeding units that did. In all four breeding units the trend was for the average number of piglets born alive to increase as the environmental temperature around the time of farrowing increased and the trend in three of the four breeding units was for the percentage of stillbirths per litter to decrease with increased temperature around the time of farrowing. The most significant observation in this study was the trend for farrowing rates to decrease following inseminations during times of high ambient temperatures $\left(>30^{\circ} \mathrm{C}\right)$. Environmental temperature control did not negate this effect, but the breeding units employing the environmental temperature control did show higher average farrowing rates overall.

\section{Introduction}

Farmers are paid for the weight of pig meat sold, thus the more pigs sold, the more the farmer and the pig industry benefit. The biggest threat to this profit is poor reproductive performance, as fewer piglets per sow means fewer carcasses sold, causing economic losses to the farmer. This also means more sows will need to be rebred, more culled and more replacement animals obtained, which causes indirect losses as well (Tast et al. 2005). There are many reasons for poor reproductive performance, including infectious causes, nutrition, management, environment and genetics, but one remains problematic, namely seasonal infertility.

Literature on the subject of seasonal infertility can be conflicting at times. This is not surprising considering the wide range of variation between the studies, which span different continents, countries, management systems, nutritional sources and disease statuses. This indicates that a local approach may be needed, as each factor contributing to the syndrome may vary in prevalence and severity in specific areas. Boma and Bilkei (2006:229-232) even stated that it is notoriously difficult and even controversial to compare published reproductive data on seasonally related reproductive problems from different authors and continents in different seasons'. In South Africa, ambient temperatures are generally relatively high and so may play a more significant role in seasonal infertility than in more temperate countries.

The term 'seasonal infertility' or 'summer infertility' has been associated with the syndrome of lowered reproductive performance during the summer season. This has been shown to be a problem in South Africa as well as various other countries by negatively affecting not only the reproductive performance but consequently the economic efficiency of pig herds (Chokoe \& Siebrits 2009). The two most important parameters in pig reproduction are the farrowing rate, as the key factor for reliable production of piglets, and the litter size, as the determinant of the amount of product that can be marketed (Bloemhof et al. 2013). 
Some studies (Prunier, Dourmad \& Etienne 1994; Tummaruk et al. 2010) concluded that temperature affected reproduction more than photoperiod. In South Africa, photoperiod does not differ drastically from summer to winter, thus the effect of season will most likely be as a result of the difference in ambient temperature.

It is suggested that seasonality in pigs cannot be accounted for by only temperature or photoperiod; most probably there is an interaction between the two (Chokoe \& Siebrits 2009). It was found, however, that decreasing the photoperiod during times of high ambient temperature will not negate the negative effects on reproductive performance (Prunier et al. 1994).

South Africa experiences relatively high environmental temperatures during summertime. This study will attempt to describe whether these periods have had an effect on the farrowing rate, litter sizes and number of stillbirths, based on field data. The sample was not of sufficient size to support statistical analysis, and the approach is therefore descriptive, but trends were identified on the basis of the data collected.

\section{Materials and methods}

Data were collected from functional commercial piggeries, specifically the breeding units. The requirements for the breeding unit to be included in the study were that the unit had to have good records of the reproductive performance of the sows in the unit, especially regarding how many sows were inseminated or mated, how many sows farrowed and the number of piglets born on a weekly basis. These data were collected in a table format, with the information presented on a week-by-week basis, from December 2010 up until the end of August 2012.

All four breeding units used are situated in the summer rainfall area. Breeding units 1 and 2 are situated in the temperate interior according to the SANS 204-2 standard whilst breeding unit 1 is 'arid, steppe, hot arid' and unit 2 is 'arid, steppe, cold arid' in the Köppen-Geiger Climate Classification. Breeding units 3 and 4 are situated in the cold interior according to the SANS 204-2 standard and are 'warm temperate, winter dry, warm summer' in the Köppen-Geiger
Climate Classification (Conradie 2012). All of the units use flush feeding prior to artificial insemination.

Breeding unit 1 has approximately 1400 sows, utilises artificial lighting and an all-in, all-out management system and weans at 28 days. The unit utilises natural ventilation with automatic side panels in the breeding houses that function with a thermostat.

Breeding unit 2 has approximately 2100 sows, utilises artificial lighting and also weans at 28 days. The unit utilises a cooling system that sprays mist from a water tower and uses extractor fans for ventilation.

Breeding unit 3 has approximately 950 sows. It utilises an all-in, all-out management system and weans at 21 days. The unit utilises natural ventilation with open-sided breeding houses.

Breeding unit 4 has approximately 1050 sows, utilises artificial lighting and an all-in, all-out management system and weans at 21 days. The unit utilises natural ventilation with movable curtains in the breeding houses.

For background information, the breeding units completed a questionnaire that included the perception of the effect of high environmental temperatures on the reproductive performance of the sows and whether any cooling mechanisms were employed during the time around mating of the sows.

\section{Results}

The average percentages for farrowing rate, the average number of piglets born alive for temperatures at mating and at farrowing and the average number of stillbirths per litter are summarised in Table 1. It should be noted that the stillbirths are as recorded by the producers and may include early neonatal deaths as well as piglets actually born dead.

The farrowing rate was consistently higher in all four units for mating at mild temperatures (Table 1). For temperatures of $22{ }^{\circ} \mathrm{C}$ and higher at mating, the farrowing rate remained fairly constant in units 1,3 and 4 , but showed a steady decrease

TABLE 1: Average data for farrowing rate, piglets born alive and stillborn in relation to temperature. Mild temperature $<22^{\circ} \mathrm{C}$; moderate temperature $22^{\circ} \mathrm{C}-30^{\circ} \mathrm{C}$; severe TABLE 1: Average data fo
temperature $>30^{\circ} \mathrm{C}$.

\begin{tabular}{|c|c|c|c|c|c|}
\hline Breeding unit & Temperatures & Average farrowing rate $(\%)$ & $\begin{array}{l}\text { Average number born alive } \\
\text { (for temperature at mating) }\end{array}$ & $\begin{array}{c}\text { Average number born alive } \\
\text { (for temperature at farrowing) }\end{array}$ & $\begin{array}{l}\text { Average number stillborn } \\
\text { per litter }\end{array}$ \\
\hline \multirow[t]{2}{*}{1} & Mild & 92.9 & 12.3 & 12.3 & 0.7 \\
\hline & Moderate & 90 & 12.6 & 12.4 & 0.8 \\
\hline \multirow[t]{3}{*}{2} & Mild & 93.5 & 11.6 & 11.6 & 1.9 \\
\hline & Moderate & 89.5 & 11.7 & 11.6 & 1.9 \\
\hline & Severe & 87.9 & 11.7 & 11.9 & 1.9 \\
\hline \multirow{2}{*}{3} & Moderate & 86.4 & 11.6 & 11.7 & 1 \\
\hline & Severe & 87.6 & 11.2 & 11.6 & 1.1 \\
\hline \multirow[t]{3}{*}{4} & Mild & 90.7 & 12.3 & 11.9 & 1 \\
\hline & Moderate & 88.8 & 12.1 & 12.2 & 1 \\
\hline & Severe & 90.1 & 12.1 & 12.2 & 1 \\
\hline
\end{tabular}




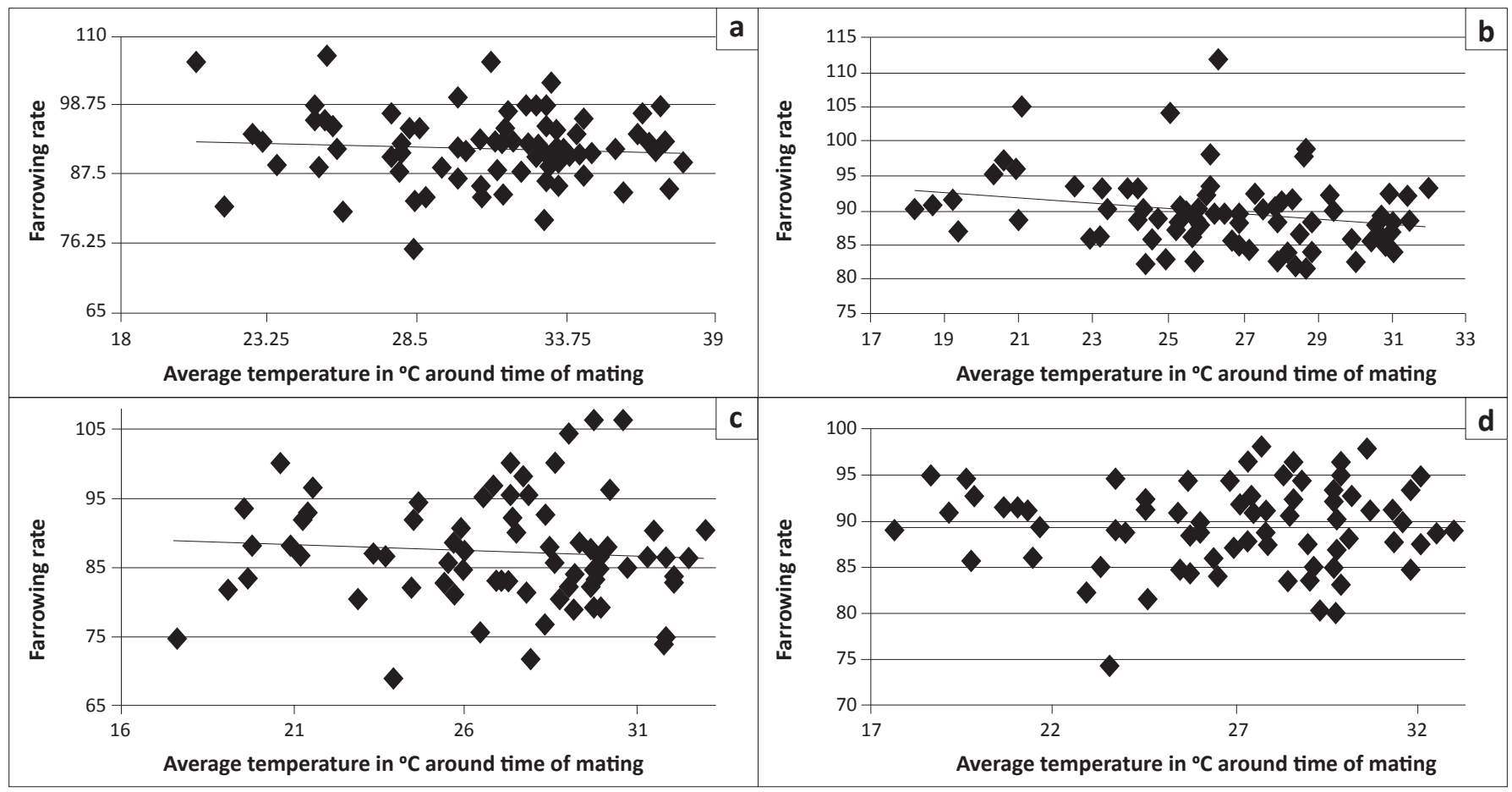

Source: Authors' own construction

FIGURE 1: Farrowing rate at various ambient temperatures around the time of mating. (a) Breeding unit 1, (b) breeding unit 2, (c) breeding unit 3 and (d) breeding unit 4.

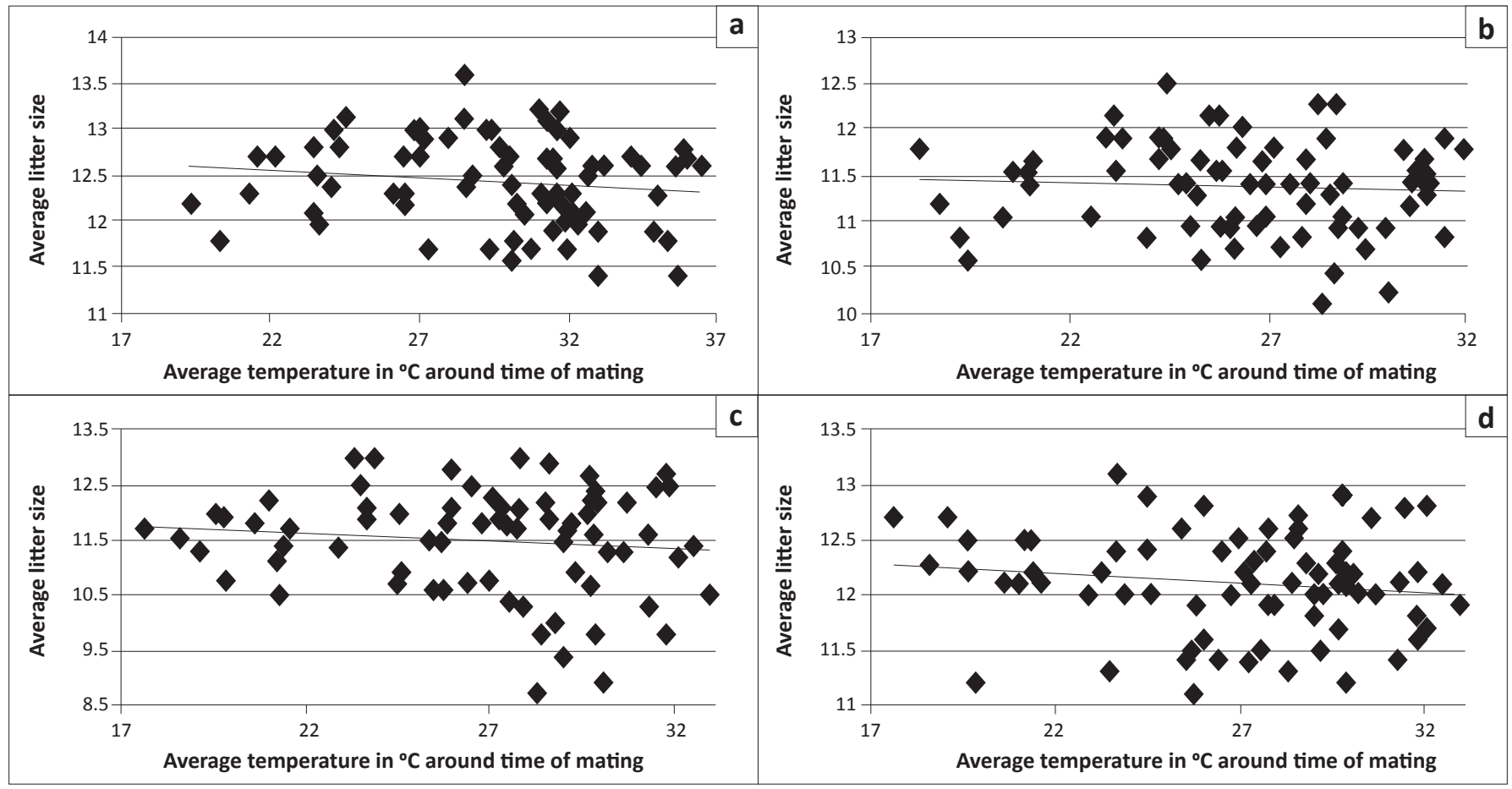

Source: Authors' own construction

FIGURE 2: The effect of various temperatures around the time of mating on litter size. (a) Breeding unit 1, (b) breeding unit 2, (c) breeding unit 3 and (d) breeding unit 4 .

in unit 2 (Table 1). Trend lines indicated that the farrowing rate decreased with increase in environmental temperature (Figure 1), with the steepest decrease in unit 2 (Figure 1b) and the least evident decrease in unit 4 (Figure 1d).

The effect of temperature on average litter size based on piglets born alive and number of stillbirths was less evident (Table 1), but trends are indicated in Figures 2-4.
The trend in all the units was for the number of piglets born alive to decrease with an increase in environmental temperature at the time of mating (Figure 2). Conversely, the average number of piglets born alive increased with increased environmental temperatures (Figure 3). The number of stillbirths was close to constant for all the units (Table 1); however, the trend lines indicated a slight increase in stillbirths with increasing environmental 


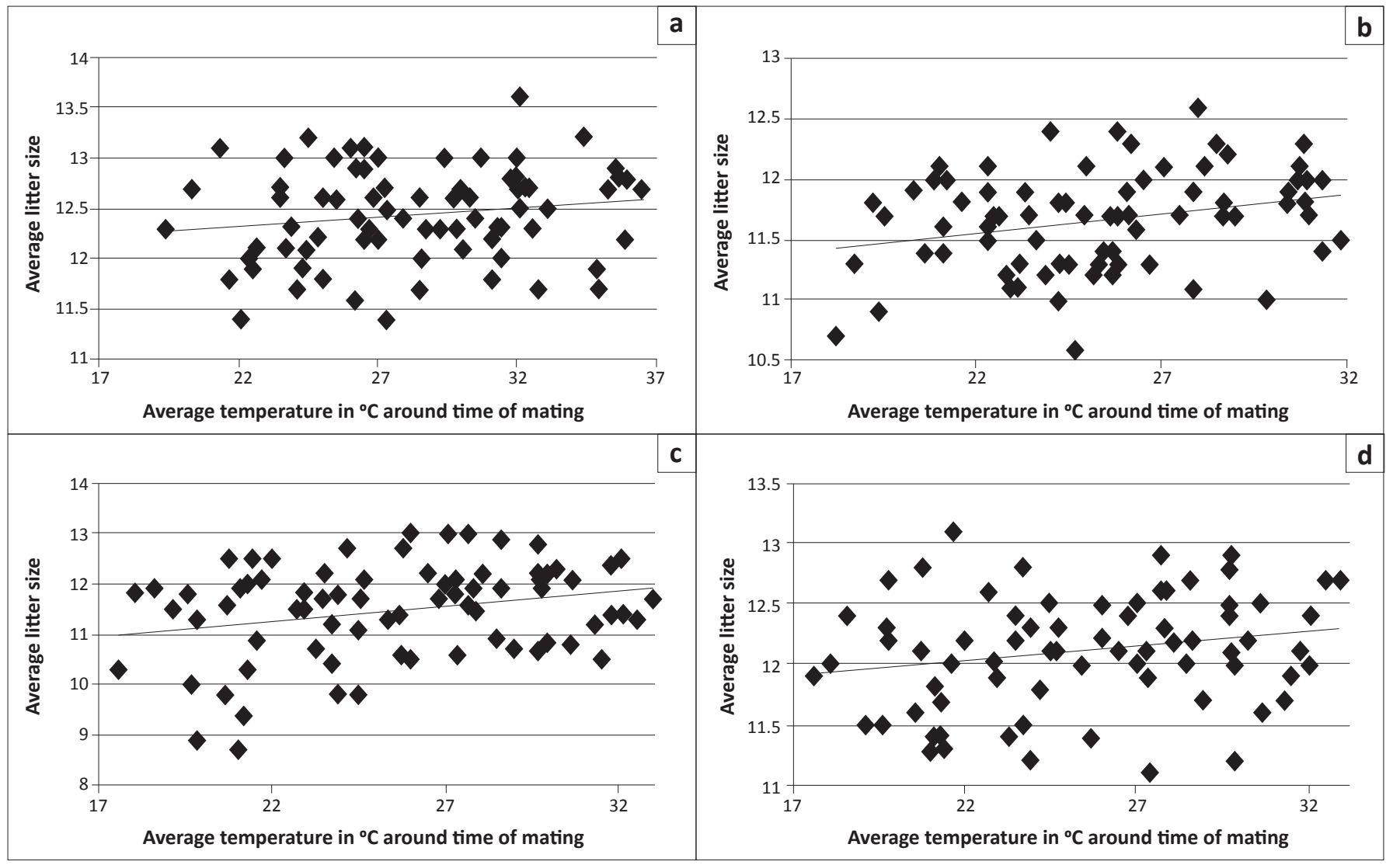

Source: Authors' own construction

FIGURE 3: The effect of various temperatures around the time of farrowing on litter size. (a) Breeding unit 1, (b) breeding unit 2, (c) breeding unit 3 and (d) breeding unit 4 .

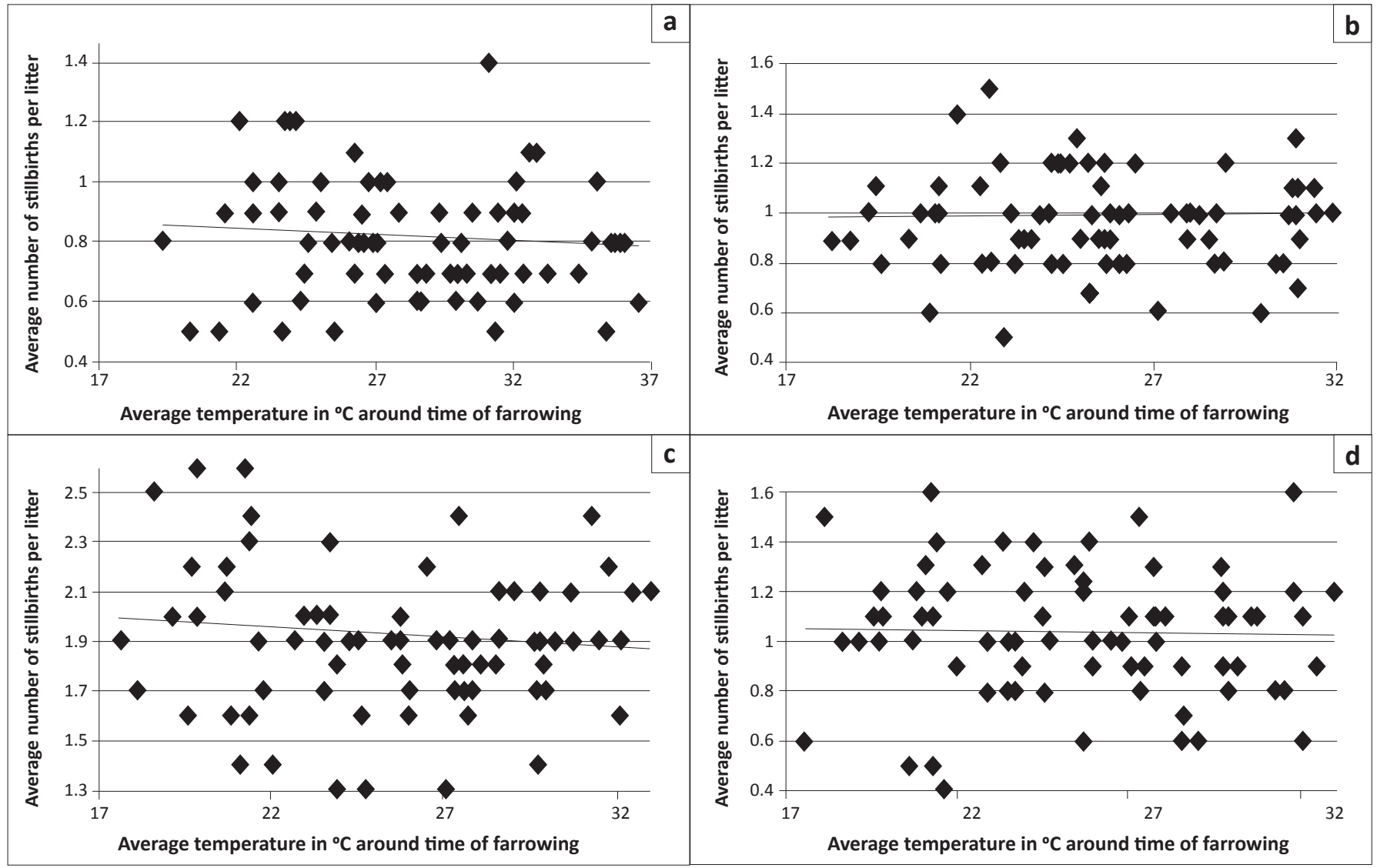

Source: Authors' own construction

FIGURE 4: The effect of various temperatures around the time of farrowing on the number of stillbirths. (a) Breeding unit 1, (b) breeding unit 2, (c) breeding unit 3 and (d) breeding unit 4 . 
temperatures in breeding unit 2 but a slight decrease with increasing temperatures in breeding units 1, 3 and 4 (Figure 4 ).

The effect of temperature control on farrowing rates did not appear to be significant (Table 2). The differences for the average litter size based on piglets born alive between mild and severe temperatures at mating and farrowing were much lower than for farrowing rates.

The differences in the number of stillbirths were also very small, and the fact that the differences in percentage lost per litter differed quite markedly between units suggest that factors other than temperatures were the most important causes of the losses.

\section{Discussion}

During the period for which the temperatures were collected, the highest average temperature was $36^{\circ} \mathrm{C}$ and the lowest average temperature was $17.6^{\circ} \mathrm{C}$ per week. Thus it can be seen that in general the average ambient temperature is in the higher range on the farms that were selected. The temperature greatest proportion of weeks was outside the pig's thermoneutral zone of $12{ }^{\circ} \mathrm{C}-22{ }^{\circ} \mathrm{C}$ (Bloemhof et al. 2008).

This study focused on describing the effects of ambient temperature on only two aspects of reproductive performance, namely farrowing rate and litter size. More studies will be needed to investigate the effect of ambient temperature on weaning to oestrus interval, weaning to conception interval, age of puberty in gilts and birth mass of piglets.

Similar to the findings of other authors (Almond \& Bilkei 2005; Boma \& Bilkei 2006; Peltoniemi, Tast \& Love 2000), it was observed in all four breeding units evaluated in this study that the trend was for the farrowing rate to decrease as the environmental temperatures increased around the time of mating.

As can be seen from Table 2, the results were similar to those found in Kenya (Boma \& Bilkei 2006), with a decrease in farrowing rate following mating during severe average temperatures $\left(>30^{\circ} \mathrm{C}\right)$ when compared to the farrowing rate following mating during mild average temperatures $\left(<22{ }^{\circ} \mathrm{C}\right)$. These results are also comparable with the results from another study (Almond \& Bilkei 2005) in Croatia as well as from a study in the French West Indies (Gourdine et al. 2006).

In a recent study (Canaday et al. 2013), it was found that under experimental conditions there was no significant difference in the farrowing rate at temperatures between $15{ }^{\circ} \mathrm{C}$ and $30{ }^{\circ} \mathrm{C}$ at the time of mating. These findings are corroborated by another study (Williams et al. 2013), as it also found no significant reproductive difference following experimental temperature control at $18{ }^{\circ} \mathrm{C}-20^{\circ} \mathrm{C}$ and $24{ }^{\circ} \mathrm{C}-30^{\circ} \mathrm{C}$. However, the authors acknowledged that the experimental conditions were perhaps not enough to simulate the irregular and erratic natural temperature conditions in the field and may have led to the sows adapting more readily to the constant high ambient temperature.

In a study performed on South African pig farms (Davies 1988), it was found that they experienced lower farrowing rates during summer compared to the rest of the year, but that this could be improved by environmental and management strategies. In the current study, environmental temperature control was only employed in breeding units 1 and 2 .

It was found that environmental temperature control did not have a significant effect on improving the difference in the farrowing rate between inseminations during mild and severe temperatures (Table 2), which is similar to the findings of other studies (Almond \& Bilkei 2005). However, the average farrowing rates throughout the year were observed to be improved in the breeding units with environmental temperature control when compared to those without (Table 3).

A recent study (Bloemhof et al. 2013) found that heat stress has the most adverse effect on farrowing rate 21 to 14 days before the first insemination. This can be correlated with the period of lactation in the sow. At this time the sow is more

TABLE 3: Average litter size following mating and following farrowing at mild and severe temperatures in association with temperature control.

\begin{tabular}{llll}
\hline Breeding unit & $\begin{array}{l}\text { Difference between } \\
\text { mild and severe } \\
\text { temperature at } \\
\text { mating }\end{array}$ & $\begin{array}{l}\text { Difference between } \\
\text { mild and severe } \\
\text { temperature at } \\
\text { farrowing }\end{array}$ & $\begin{array}{l}\text { Environmental } \\
\text { temperature control }\end{array}$ \\
\hline 1 & 0 & +0.2 & Yes \\
2 & +0.1 & +0.3 & Yes \\
3 & -0.3 & +0.6 & No \\
4 & -0.2 & +0.3 & No \\
\hline
\end{tabular}

TABLE 4: Average number of stillbirths with farrowing at mild and severe temperatures.

\begin{tabular}{lcccccccc}
\hline Breeding unit & \multicolumn{2}{c}{ Mild temperature } & & \multicolumn{2}{c}{ Severe temperature } & & \multicolumn{2}{c}{ Difference } \\
\cline { 2 - 3 } & $\begin{array}{c}\text { Stillborn } \\
\text { per litter }\end{array}$ & $\begin{array}{c}\text { As \% of } \\
\text { litter }\end{array}$ & & $\begin{array}{c}\text { Stillborn } \\
\text { per litter }\end{array}$ & $\begin{array}{c}\text { As \% of } \\
\text { litter }\end{array}$ & & $\begin{array}{c}\text { Stillborn } \\
\text { per litter }\end{array}$ & $\begin{array}{c}\text { As \% of } \\
\text { litter }\end{array}$ \\
\hline 1 & 0.7 & 5.7 & & 0.8 & 6.4 & & +0.1 & +0.7 \\
2 & 1.9 & 16.4 & & 1.9 & 16.0 & 0 & -0.4 \\
3 & 1.2 & 10.9 & & 1.1 & 9.5 & & -0.1 & -1.4 \\
4 & 1 & 8.4 & 1 & 8.2 & & 0 & -0.2 \\
\hline
\end{tabular}

TABLE 2: Farrowing rates (\%) for different breeding units associated with temperature control.

\begin{tabular}{|c|c|c|c|c|c|}
\hline Breeding unit & $\begin{array}{c}\text { Average farrowing rate per } \\
\text { year }(\%)\end{array}$ & $\begin{array}{l}\text { Average farrowing rate at } \\
\text { mild temperatures (\%) }\end{array}$ & $\begin{array}{l}\text { Average farrowing rate at } \\
\text { severe temperatures (\%) }\end{array}$ & $\begin{array}{c}\text { Difference between mild and } \\
\text { severe temperatures }(\%)\end{array}$ & $\begin{array}{c}\text { Environmental } \\
\text { temperature control }\end{array}$ \\
\hline 1 & 91.1 & 92.9 & 90.5 & -2.5 & Yes \\
\hline 2 & 90.3 & 93.5 & 87.9 & -5.6 & Yes \\
\hline 4 & 89.9 & 90.7 & 90.1 & -0.6 & No \\
\hline
\end{tabular}


susceptible to heat stress and the resultant decrease in feed intake could result in decreased levels of luteinizing hormone, which could hamper follicle development. If the minimum number of embryos is not produced for maternal recognition of pregnancy to occur, sows will return to oestrus, resulting in a lowered farrowing rate. Further studies in South Africa are required to determine if this is the most sensitive time period for sows under local conditions.

The observations of this study with regard to the trends for litter sizes (Table 3) were similar to those in other studies (Boma \& Bilkei 2006; Quesnel, Boulot \& Cozier 2005; Tummaruk et al. 2010), following mating and early gestation with high ambient temperature. When insemination occurred at higher temperatures, the resultant litter size was marginally decreased in the breeding units that did not employ environmental temperature control, but was unaffected in the breeding units which did. However, it did not have a significant influence on the average number of piglets born alive. It was recently found (Bloemhof et al. 2013) that litter size was most affected when sows underwent heat stress from 7 days before insemination to 12 days after, with the most significant day being the day of insemination.

In all four breeding units the trend was for the average number of piglets born alive to increase as the environmental temperature around the time of farrowing increased (Figure 3; Table 3). This could possibly be a result of the effect of the environmental temperature on the piglets rather than the sows, improving the survivability of the piglets around the birthing process. It was shown in another study (Malmkvist et al. 2012) that supplementary floor heating in the farrowing pen increased the survivability of neonatal piglets. It is also noteworthy that sows farrowing during higher environmental temperatures would have been mated during times of milder environmental temperatures. A study investigating the effect of ambient temperature per week of gestation on the number of piglets born alive would be beneficial to identify the critical times of gestation with regard to improving litter size.

Previous studies (Babicz et al. 2012; Tummaruk et al. 2010; Vanderhaeghe et al. 2010) have found that high ambient temperatures around the time of farrowing increased the number of stillbirths. The current study shows that the trend in three of the four breeding units was for the percentage of stillbirths per litter to decrease with increasing temperature around the time of farrowing (Table 4), which is contrary to the abovementioned findings. This possibly could be attributed to improved viability of the piglets at higher temperatures. However, one of the four breeding units showed a tendency for the percentage of stillbirths per litter to increase at higher temperatures at farrowing, similar to the findings of the abovementioned studies.

\section{Conclusion}

The most important observation of this study was the trend for farrowing rates to decrease following inseminations during times of high ambient temperatures (>30 ${ }^{\circ} \mathrm{C}$ ).
Environmental temperature control did not altogether cancel out this effect, but the breeding units employing the environmental temperature control did show higher average farrowing rates overall.

\section{Acknowledgements}

The authors wish to acknowledge the South African Weather Service for the temperature information provided, as well as the farms who participated in this study.

\section{Competing interests}

The authors declare that they have no financial or personal relationship(s) that may have inappropriately influenced them in writing this article.

\section{Authors' contributions}

L.J.v.R. (Department of Agriculture, Forestry and Fisheries) was the project leader. B.T.S. (University of Pretoria) provided guidance on the study design and the interpretation of the results. L.J.v.R. drafted the article, which was revised by B.T.S.

\section{References}

Almond, P.K. \& Bilkei, G., 2005, 'Seasonal infertility in large pig production units in an Eastern-European climate', Australian Veterinary Journal 83, 344-346. http:// dx.doi.org/10.1111/j.1751-0813.2005.tb15627.x

Babicz, M., Skrzypczak, E., Rejduch, B., Kozubska-Sobocińska, A., ChmielowiecKorzeniowska, A. \& Kasprzak, C., 2012, 'Effect of thermal stress on reproductive
performance parameters of sows with defined genotype at the RYR1 locus', Annals of Animal Science 12, 323-333. http://dx.doi.org/10.2478/v10220-012-0027-1

Bloemhof, S., Mathur, P.K., Knol, E.F. \& Van der Waaij, E.H., 2013, 'Effect of daily environmental temperature on farrowing rate and total born in dam line sows', Journal of Animal Science 91, 2667-2679. http://dx.doi.org/10.2527/jas.2012Journal
5902

Bloemhof, S., Van der Waaij, E.H., Merks, J.W.M. \& Knol, E.F., 2008, 'Sow line differences in heat stress tolerance expressed in reproductive performance traits', Journal of Animal Science 86, 3330-3337. http://dx.doi.org/10.2527/jas.2008-0862

Boma, M.H. \& Bilkei, G., 2006, 'Seasonal infertility in Kenyan pig breeding units', Onderstepoort Journal of Veterinary Research 73, 229-232. http://dx.doi. org/10.4102/ojvr.v73i3.149

Canaday, D.C., Salak-Johnson, J.L., Viscunti, A.M., Wang, X., Bhalerao, K. \& Knox, R.V., 2013, 'Effect of variability in lighting and temperature environments for mature gilts housed in gestation crates on measures of reproduction and animal wellbeing', Journal of Animal Science 91, 1225-1236. http://dx.doi.org/10.2527/ jas.2012-5733

Chokoe, T.C. \& Siebrits, F.K., 2009, 'Effects of season and regulated photoperiod on the reproductive performance of sows', South African Journal of Animal Science $115,317-322$.

Conradie, D.C.U., 2012, 'South Africa's climatic zones: Today, tomorrow', Future trends and issues impacting on the built environment, Sandton, South Africa, July 25-26, 2012.

Davies, P.V.A., 1988, 'The influence of sow management systems on seasonal infertility', Proceedings of the Tenth International Pig Veterinary Society Meeting, Rio de Janeiro, Brazil, August 14-17, 1988, p. 297.

Gourdine, J.L., Quesnel, H., Bidanel, J-P. \& Renaudeau, D., 2006, 'Effect of season, parity and lactation on reproductive performance of sows in a tropical humid climate', Asian-Australasian Journal of Animal Sciences 19, 1111-1119. http:// dx.doi.org/10.5713/ajas.2006.1111

Malmkvist, J., Pedersen, L.J., Kammersgaard, T.S. \& Jørgensen, E., 2012, 'Influence of thermal environment on sows around farrowing and during the lactation period', Journal of Animal Science 90, 3186-3199. http://dx.doi.org/10.2527/jas.20114342

Peltoniemi, O.A.T., Tast, A. \& Love, R.J., 2000, 'Factors affecting reproduction in the pig: Seasonal effects and restricted feeding of the pregnant gilt and sow', Animal Reproduction Science 60-61, 173-184. http://dx.doi.org/10.1016/S03784320(00)00092-0

Prunier, A., Dourmad, J.Y. \& Etienne, M., 1994, 'Effect of light regimen under various ambient temperatures on sow and litter performance', Journal of Animal Science 72, 1461-1466. 
Quesnel, H., Boulot, S. \& Cozier, Y., 2005, 'Seasonal variation of reproductive performance of the sow', INRA Productions Animales 18, 101-110.

Tast, A., Hälli, O., Virolainen, J.V., Oravainen, J., Heinonen, M. \& Peltoniemi, O.A.T. 2005 , 'Investigation of a simplified artificial lighting programme to improve the fertility of sows in commercial piggeries', Veterinary Record 156, 702-705.

Tummaruk, P., Tantasuparuk, W., Techakumphu, M. \& Kunavongkrit, A., 2010 'Seasonal influences on the litter size at birth of pigs are more pronounced in the gilt than sow litters', Journal of Agricultural Science 148, 421-432. http://dx.doi. org/10.1017/S0021859610000110
Vanderhaeghe, C., Dewulf, J., Ribbens, S., DeKruif, A. \& Maes, D., 2010, 'A crosssectional study to collect risk factors associated with stillbirths in pig herds', Animal Reproduction Science 118, 62-68. http://dx.doi.org/10.1016/j. Animal Reproduction

Williams, A.M., Safranski, T.J., Spiers, D.E., Eichen, P.A., Coate, E.A. \& Lucy, M.C. 2013 , 'Effects of a controlled heat stress during late gestation, lactation and after weaning on thermoregulation, metabolism, and reproduction of primiparous sows', Journal of Animal Science 91, 2700-2714. http://dx.doi.org/10.2527/ jas.2012-6055 